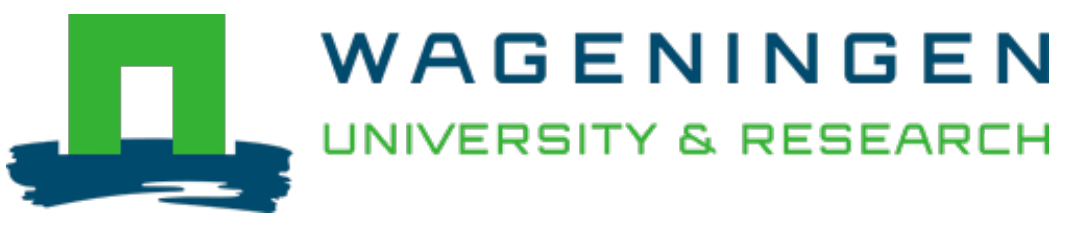

\title{
Soya bean tempe extracts show antibacterial activity against Bacillus cereus cells and spores
}

\author{
Journal of Applied Microbiology \\ Roubos-van den Hil, P.J.; Dalmas, E.; Nout, M.J.R.; Abee, T. \\ https://doi.org/10.1111/j.1365-2672.2009.04637.x
}

This publication is made publicly available in the institutional repository of Wageningen University and Research, under the terms of article $25 \mathrm{fa}$ of the Dutch Copyright Act, also known as the Amendment Taverne. This has been done with explicit consent by the author.

Article 25 fa states that the author of a short scientific work funded either wholly or partially by Dutch public funds is entitled to make that work publicly available for no consideration following a reasonable period of time after the work was first published, provided that clear reference is made to the source of the first publication of the work.

This publication is distributed under The Association of Universities in the Netherlands (VSNU) 'Article $25 \mathrm{fa}$ implementation' project. In this project research outputs of researchers employed by Dutch Universities that comply with the legal requirements of Article $25 \mathrm{fa}$ of the Dutch Copyright Act are distributed online and free of cost or other barriers in institutional repositories. Research outputs are distributed six months after their first online publication in the original published version and with proper attribution to the source of the original publication.

You are permitted to download and use the publication for personal purposes. All rights remain with the author(s) and / or copyright owner(s) of this work. Any use of the publication or parts of it other than authorised under article $25 \mathrm{fa}$ of the Dutch Copyright act is prohibited. Wageningen University \& Research and the author(s) of this publication shall not be held responsible or liable for any damages resulting from your (re)use of this publication.

For questions regarding the public availability of this publication please contact openscience.library@wur.nl 
ORIGINAL ARTICLE

\title{
Soya bean tempe extracts show antibacterial activity against Bacillus cereus cells and spores
}

\author{
P.J. Roubos-van den Hil, E. Dalmas, M.J.R. Nout and T. Abee \\ Laboratory of Food Microbiology, Wageningen University, Wageningen, the Netherlands
}

\begin{abstract}
Keywords
activity, antibacterial, Bacillus cereus, spores, tempe.

\section{Correspondence}

Petra J. Roubos-van den Hil, Laboratory of Food Microbiology, Wageningen University, Bomenweg 2, $6703 \mathrm{HD}$ Wageningen, the Netherlands. E-mail: Petra.Roubos@wur.nl

2009/1414: received 10 August 2009, revised 9 November 2009 and accepted 21 November 2009
\end{abstract}

doi:10.1111/j.1365-2672.2009.04637.x

\begin{abstract}
Aims: Tempe, a Rhizopus ssp.-fermented soya bean food product, was investigated for bacteriostatic and/or bactericidal effects against cells and spores of the food-borne pathogen Bacillus cereus.

Methods and results: Tempe extract showed a high antibacterial activity against B. cereus ATCC 14579 based on optical density and viable count measurements. This growth inhibition was manifested by a $4 \log \mathrm{CFU} \mathrm{ml} l^{-1}$ reduction, within the first $15 \mathrm{~min}$ of exposure. Tempe extracts also rapidly inactivated B. cereus spores upon germination. Viability and membrane permeability assessments using fluorescence probes showed rapid inactivation and permeabilization of the cytoplasmic membrane confirming the bactericidal mode of action. Cooked beans and Rhizopus grown on different media did not show antibacterial activity, indicating the unique association of the antibacterial activity with tempe. Subsequent characterization of the antibacterial activity revealed that heat treatment and protease addition nullified the bactericidal effect, indicating the proteinaceous nature of the bioactive compound.

Conclusions: During fermentation of soya beans with Rhizopus, compounds are released with extensive antibacterial activity against B. cereus cells and spores.

Significance and Impact of Study: The results show the potential of producing natural antibacterial compounds that could be used as ingredients in food preservation and pathogen control.
\end{abstract}

\section{Introduction}

Tempe is the collective name for a sliceable mass of precooked fungal-fermented beans, cereals or some other food processing by-products bound together by the mycelium of a living mould (mostly Rhizopus spp.). Yellowseeded soya beans are the most common and preferred raw material to make tempe. Traditional manufacture of tempe includes two major steps, namely a soaking process of the raw beans, where beans are acidified by natural occurring lactic acid bacteria. This is followed by a fungal fermentation initiated by an added mould starter culture. The purpose of the fermentation is not as much to enhance preservation, but rather the modification of ingredients and an increase of the nutritional properties because of enzymatic activity (Nout and Kiers 2005).
Previous investigations by Wang et al. (1969) showed that tempe contains antibacterial properties against some Gram-positive bacteria. These were associated with the mould Rhizopus oligosporus. In 1992, an antibiotic substance produced by R. oligosporus grown in culture broth was purified (Kobayasi et al. 1992) and found to be active against Bacillus subtilis vegetative cells. Neither further investigations of this antibacterial effect, nor the effect of tempe extracts on Bacillus spores has been published since.

The present article deals with the antibacterial effect of soya bean tempe on B. cereus vegetative cells and spores. Bacillus cereus is a Gram-positive, spore forming bacterium, able to cause two types of food poisoning: the diarrhoeal type by enterotoxin production in the small intestine and the emetic type by cereulide, a toxin 
produced during growth in food (Kotiranta et al. 2000). Bacillus cereus is ubiquitous in nature and frequently isolated from soil and plants. As a common inhabitant of soils, the organism can easily be transmitted to vegetation and hence to foods (Notermans and Batt 1998; Stenfors Arnesen et al. 2008).

The potential use of natural antimicrobials such as bacteriocins, for the improvement of microbial quality and safety of food has stimulated intensive research efforts in recent years (Galvez et al. 2007; Settanni and Corsetti 2008). An antibacterial compound produced by tempe processing may be of considerable interest, because of its natural food-based origin. Inhibition of spoilage caused by outgrowth of bacterial spores may be an additional target for application, because of the resistance of spores to several preservation techniques.

Pathogenic organisms are also developing more resistance to conventional antibiotics. This problematic trend has generated an increased interest in the pharmacological application of antimicrobial peptides to cure infections (Epand and Vogel 1999). Food-based antibacterial compounds may not only be important for food preservation but can possibly also be used to control pathogens and prevent human infections (Cotter et al. 2005).

In the present study, the antibacterial activity of tempe is investigated with B. cereus as the target organism. The activity is not only tested against vegetative cells, but also against spores. Furthermore, the origin of the active component by testing the intermediate stages of processing and fermentation strains separately is determined. Experiments are performed to give details about the mode of action and characteristics of the active component.

\section{Materials and methods}

\section{Tempe processing}

Dry-dehulled full-fat yellow-seeded soya beans (Glycine max) were soaked overnight in tap water at $30^{\circ} \mathrm{C}$. Tap water was enriched with $10 \%$ naturally acidified soaking water from previous soya bean soaking steps, according to the 'backslop' procedure (Nout et al. 1987). After overnight incubation, soya beans were rinsed with tap water and cooked in fresh tap water for $20 \mathrm{~min}$ (ratio soaked beans: water $1: 3$ ) and cooled by evaporation of adhering moisture at room temperature. Soya beans were inoculated with a sporangiospore suspension of Rhizopus microsporus var. microsporus (LU 573). This suspension was prepared by scraping off the sporangia from pure cultures grown on malt extract agar slants (CM59; Oxoid, Basingstoke, UK) for 7 days at $30^{\circ} \mathrm{C}$, in peptone physiological salt (PPS)
$(0 \cdot 85 \% \mathrm{NaCl}$ and $0 \cdot 1 \%$ peptone solution). After inoculation with the sporangiospore suspension $\left(10 \mathrm{ml} \mathrm{kg}^{-1}\right.$ corresponding to an initial inoculum level of $10^{6} \mathrm{CFU} \mathrm{g}^{-1}$ beans), the soya beans (batches of $450 \mathrm{~g}$ ) were packed in hard-plastic, perforated boxes $(205 \times 90 \times 45 \mathrm{~mm})$ and incubated at $30^{\circ} \mathrm{C}$ for $24,48,72,96$ and $120 \mathrm{~h}$.

\section{Soya extract preparation}

Fermented soya beans (tempe) and cooked soya beans, were freeze-dried and grounded passing through a $0 \cdot 5$ mm sieve (Ultra Centrifugal Mill ZM 200, Retsch GmbH, Haan, Germany) and were stored at $-20^{\circ} \mathrm{C}$ until further processing.

Freeze-dried products were suspended in distilled water $\left(60 \mathrm{~g} \mathrm{l}^{-1}\right)$ and stirred with a magnetic stirrer for $3 \mathrm{~h}$ at room temperature. The $\mathrm{pH}$ was continually checked and adjusted to $\mathrm{pH} 8.0$ with $1 \mathrm{~mol}^{-1} \mathrm{NaOH}$. To obtain clear supernatants, the soluble extract was obtained by three consecutive centrifugation steps $\left(10 \mathrm{~min}, 10000 \mathrm{~g}, 20^{\circ} \mathrm{C}\right)$. Supernatants were freeze-dried and soluble dry matter was stored at $-20^{\circ} \mathrm{C}$ and used as soya bean soluble dry matter in experiments.

\section{Mould extract preparation}

Rhizopus microsporus var. microsporus (LU 573) was grown on different liquid and solid media, to test the antibacterial activity of the mould biomass. Rhizopus sporangiospores were inoculated in malt extract broth (MEB, CM59; Oxoid, Basingstoke, UK) and mineral medium (MIB) containing $\mathrm{NH}_{4} \mathrm{Cl}\left(5 \mathrm{mmol} \mathrm{l}^{-1}\right)$, D-glucose $\left(25 \mathrm{mmol} \mathrm{l}^{-1}\right), \mathrm{MgSO}_{4} .7 \mathrm{H}_{2} \mathrm{O}\left(1 \cdot 3 \mathrm{mmol} \mathrm{l}^{-1}\right), \mathrm{ZnSO}_{4} .7 \mathrm{H}_{2} \mathrm{O}$ $\left(0 \cdot 3 \mathrm{mmol} \mathrm{l}^{-1}\right), \mathrm{MnSO}_{4} \cdot 4 \mathrm{H}_{2} \mathrm{O}\left(0 \cdot 2 \mathrm{mmol} \mathrm{l}^{-1}\right), \mathrm{FeCl} .6 \mathrm{H}_{2} \mathrm{O}$ $\left(70 \mu \mathrm{mol} \mathrm{l}^{-1}\right), \mathrm{CuSO}_{4} \cdot 5 \mathrm{H}_{2} \mathrm{O}\left(40 \mu \mathrm{mol} \mathrm{l}^{-1}\right)$ and EDTA $\left(1.2 \mathrm{mmol} \mathrm{l}^{-1}\right)$ in a $0.01 \mathrm{~mol} \mathrm{l}^{-1} \mathrm{~K}$-phosphate buffer and grown for 4 days in a shaking incubator $\left(30^{\circ} \mathrm{C}\right.$,

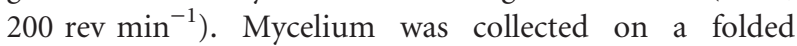
paper filter (no. 311651; Schleicher \& Schuell GmbH, Germany) and washed three times with PPS by centrifugation $\left(10 \mathrm{~min}, 3000 \mathrm{~g}, 20^{\circ} \mathrm{C}\right)$. The pellet was freezedried and stored at $-20^{\circ} \mathrm{C}$ until use. After removal of the mould biomass, the postgrowth media were also freezedried and prepared for the activity assay, to test the effect of released fungal components. Rhizopus microsporus was also grown on plates of Malt Extract agar (MEA) and cooked soya bean agar (CSBA) $\left(30 \mathrm{~g} \mathrm{l}^{-1}\right.$ freeze-dried cooked soya beans powder and $15 \mathrm{~g} \mathrm{l}^{-1}$ agar) for 4 days at $30^{\circ} \mathrm{C}$, followed by scraping off the mycelium from the agar plates and freeze drying of the mycelium. The collected mycelium extract and postgrowth media extracts were prepared in the same way as described for the soya bean extracts. 


\section{Bacteria and culture conditions}

Bacilus cereus strain ATCC 14579 was used for investigation of the tempe antibacterial effect. Stock cultures were stored at $-80^{\circ} \mathrm{C}$ in $25 \%$ glycerol. Prior to experiments, strains were inoculated in Brain Heart Infusion broth (BHI, 237500, Becton Dickinson, France) and grown for $16-18 \mathrm{~h}$ at $30^{\circ} \mathrm{C}$ in a shaking incubator $\left(200 \mathrm{rev} \mathrm{min}^{-1}\right)$.

Spores were obtained from an overnight culture of B. cereus ATCC14579 grown in tubes with $5 \mathrm{ml}$ Luria Broth (LB; 241420, Becton Dickinson, France) at $30^{\circ} \mathrm{C}$ and $200 \mathrm{rev} \mathrm{min}^{-1}$ rotary shaking. Then, cells were inoculated in maltose sporulation medium (MSM) based on the sporulation medium used by Schaeffer et al. (1965) fortified with sporulation elements of the defined medium for B. cereus and maltose to increase the yield. The MSM contained Nutrient Broth $\left(8 \mathrm{~g} \mathrm{l}^{-1}\right.$; NB, 234000, Becton Dickinson, France), maltose $\left(10 \mathrm{mmol} \mathrm{l}^{-1}\right)$, $\left(\mathrm{NH}_{4}\right)_{2} \mathrm{SO}_{4}\left(5 \mathrm{mmol} \mathrm{l}^{-1}\right), \mathrm{MgCl}_{2}\left(1 \mathrm{mmol} \mathrm{l}^{-1}\right), \mathrm{Ca}\left(\mathrm{NO}_{3}\right)_{2}$ $\left(1 \mathrm{mmol} \mathrm{l}^{-1}\right), \mathrm{FeSO}_{4}\left(1 \mathrm{mmol} \mathrm{l}^{-1}\right), \mathrm{MnSO}_{4}\left(66 \mu \mathrm{mol} \mathrm{l}^{-1}\right)$, $\mathrm{ZnCl}_{2}\left(12 \cdot 5 \mu \mathrm{mol} \mathrm{l}^{-1}\right), \mathrm{CuCl}_{2}\left(2 \cdot 5 \mu \mathrm{mol} \mathrm{l}^{-1}\right), \mathrm{Na}_{2} \mathrm{MoO}_{4}$ $\left(2 \cdot 5 \mu \mathrm{mol} \mathrm{l}^{-1}\right)$ and $\mathrm{CoCl}_{2}\left(2 \cdot 5 \mu \mathrm{mol} \mathrm{l}{ }^{-1}\right)$. Sporulation was performed in $50 \mathrm{ml} \mathrm{MSM}$ in 250-ml Erlenmeyer flasks, at $30^{\circ} \mathrm{C}$ and $200 \mathrm{rev} \mathrm{min}^{-1}$ rotary shaking. Sporulation efficiency was determined by microscopical observation and droplet plating before and after heating of sporulating cultures. To obtain spore batches containing (>95\%) spores only, as controlled microscopically, spores were washed in $10 \mathrm{mmol}^{-1}$ potassium phosphate buffer $(\mathrm{pH}$ $7 \cdot 4$ ), at least 10 times during the first 3 weeks, before starting any further experiments. Spore suspensions were stored at $4^{\circ} \mathrm{C}$ and washed weekly to prevent spontaneous germination.

The antibacterial spectrum of tempe was tested on the following strains: B. cereus ATCC 10987, NIZO B437, PAL 20, PAL28, 55, Bacillus weihenstephanensis DSM11821T and B. subtilis B20010. All strains were inoculated in BHI broth and grown for $16-18 \mathrm{~h}$ at $30^{\circ} \mathrm{C}$ with rotary shaking $\left(200 \mathrm{rev} \mathrm{min}^{-1}\right.$ ) before experiments.

\section{Antibacterial activity assay}

Two different methods were used: (i) monitoring bacterial biomass by optical density and (ii) viable count enumeration. In both methods, soya bean dry matter $\left(20 \mathrm{~g} \mathrm{l}^{-1}\right)$ was dissolved in distilled water by mixing for $3 \mathrm{~h}$ on a head-over-tail rotator, followed by centrifugation $\left(10 \mathrm{~min}, 16000 \mathrm{~g}, 20^{\circ} \mathrm{C}\right)$ and filter sterilization $(0 \cdot 22 \mu \mathrm{m}$, FP30/0-2CA-S, Schleicher \& Schuell GmbH, Germany). The $\mathrm{pH}$ of the extract was around 7. The sterile filtrate was diluted $1: 1$ in double-concentrated BHI to achieve a $10 \mathrm{~g} \mathrm{l}^{-1}$ extract in growth medium or was diluted further in BHI.
For optical density (OD) measurement, $50 \mu \mathrm{l}$ of a suspension containing $10^{6} \mathrm{CFU} \mathrm{ml}^{-1}$ vegetative cells or spores were inoculated in $200 \mu \mathrm{l}$ of BHI with or without tempe extract, in 96-well microtiter plates in triplicate. For each experiment, inoculation levels were verified by viable counts on BHI-agar. Microtiter plates were incubated in a spectrophotometer plate reader (SpectraMax Plus 384, Molecular Devices Ltd, Wokingham, Berkshire, $\mathrm{UK})$ at $30^{\circ} \mathrm{C}$ up to $24 \mathrm{~h}$. Optical density was measured every minute at $600 \mathrm{~nm}$. Prior to each measurement, the plate was shaken for $45 \mathrm{~s}$ to ensure homogeneity and optimal aerobic growth conditions. The antibacterial activity is expressed as the growth delay in h:

$$
\text { Growth delay }(\mathrm{h})=t_{\mathrm{OD}=0.6}, \exp -t_{\mathrm{OD}=0.6} \text {, control }
$$

Growth delay is defined as the time B. cereus growing in BHI with tempe extract (exp) needed to reach an OD of 0.6 minus the time B. cereus in BHI (control) needed to reach this OD-point. Data represent means and standard deviations of triplicate measurements.

During viable count enumeration experiments, BHI broth with or without tempe extract was inoculated in the same ratio medium/inoculation $(4: 1)$ as performed in the optical density measurement and was incubated at $30^{\circ} \mathrm{C}$ with continuous shaking $\left(200 \mathrm{rev} \mathrm{min}^{-1}\right)$. Samples were taken at different time points, diluted with PPS and plated in duplicate on BHI-agar.

\section{Microscopic observations}

During viable count enumeration, B. cereus cells and spores were investigated microscopically. Bacterial cells were collected by centrifugation $\left(3 \mathrm{~min}, 1520 \mathrm{~g}, 20^{\circ} \mathrm{C}\right)$, suspended in PPS and observed by phase-contrast microscope (magnification 1000×).

For viability determination, a fluorescence double staining technique was used. The green fluorescent SYTO 9 and the red-fluorescent propidium iodide (PI) (Live/ Dead Baclight Viability Kit, InVitrogen L7012; Breda, the Netherlands) were mixed in a $1: 1$ dye mixture. Bacillus cereus cells or spores were resuspended to $10^{8} \mathrm{CFU} \mathrm{ml}^{-1}$ in a bovine serum albumin-saline solution $\left(2.5 \mathrm{~g}^{-1} \mathrm{BSA}\right.$ with $\left.0.15 \mathrm{~mol} \mathrm{l}^{-1} \mathrm{NaCl}\right) ; 1 \mathrm{ml}$ of cell suspension was mixed with $2 \mu$ l dye mixture and incubated in the dark on ice for $15 \mathrm{~min}$. The stained B. cereus cells were observed with a fluorescence microscope.

\section{Effect of $\mathrm{pH}$, enzymes and heat on antibacterial activity}

Tempe extracts were prepared as described for the antibacterial activity assays. Different treatments were performed as follows. 
To investigate any inhibitory effect of $\mathrm{pH}$, the extracts were adjusted by addition of $1 \mathrm{~mol} \mathrm{l}^{-1} \mathrm{NaOH}$ or $1 \mathrm{~mol} \mathrm{l}^{-1} \mathrm{HCl}$ from $\mathrm{pH} 2 \cdot 0$ up to $\mathrm{pH} 9 \cdot 0$. For low $\mathrm{pH}$ $(2 \cdot 0,3 \cdot 0$ and $4 \cdot 0)$, the tempe extract solution was adjusted with $1 \mathrm{~mol} \mathrm{l}^{-1} \mathrm{HCl}$, mixed for an hour, centrifuged and supernatant was neutralized again to $\mathrm{pH} 7$ with $\mathrm{NaOH}$ before antibacterial activity was measured.

Tempe extracts were incubated with different enzymes of ample concentration $\left(10 \mathrm{mg} \mathrm{ml}^{-1}\right)$ at $30^{\circ} \mathrm{C}$ with

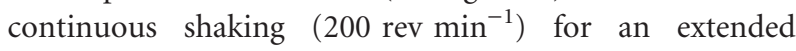
period of $4 \mathrm{~h}$ to allow degradation of all susceptible material. The following enzymes were used: Pronase E (P5147), Proteinase K (P8044), Trypsin (T0134), $\alpha$-Chymotrypsin (C4129) and Protease type XII (P2143) all from Sigma-Aldrich. Enzymes were not inactivated, because $B$. cereus growth was not affected by their presence as confirmed by control experiments with enzyme solutions only (data not shown).

Tempe extracts were heated for $20 \mathrm{~min}$ at $20,30,40$, $50,60,70,80,90$ and $100^{\circ} \mathrm{C}$ in a water bath. After heating, the samples were immediately cooled down till $4^{\circ} \mathrm{C}$, followed by measurement of their antibacterial activity.

After the treatments mentioned previously, tempe extracts were centrifuged and diluted with BHI as performed in antibacterial activity assay. Then, they were inoculated with $B$. cereus and the antibacterial activity was measured by optical density growth measurements.

\section{Results}

The impact of soya bean extracts on Bacillus cereus vegetative cells growth

Growth of B. cereus was assessed in BHI with or without addition of soya bean extracts. Figure 1(a) shows the optical density increase during the 24-h incubation at $30^{\circ} \mathrm{C}$ and Fig. $1 \mathrm{~b}$ shows the viable count enumeration of $B$. cereus using the same soya beans extracts performed simultaneously. The growth of B. cereus in BHI with or without addition of $10 \mathrm{~g} \mathrm{l}^{-1}$ cooked beans was similar, whereas the growth of B. cereus in BHI with $10 \mathrm{gl}^{-1}$ tempe added showed a growth delay of $12 \cdot 31 \mathrm{~h} \pm 0 \cdot 22$ (mean \pm standard deviation) (Fig. 1a) and a reduction in viable count of $3.7 \log \mathrm{CFU} \mathrm{ml}{ }^{-1}$ (Fig. 1b). This reduction in viable count occurred within the first $30 \mathrm{~min}$ of measurement, indicating a remarkable bactericidal effect.

Bacillus cereus viability was also analysed microscopically using fluorescent live/dead staining. After $15 \mathrm{~min}$ of incubation, B. cereus cells in BHI with added tempe extract were fluorescent red-stained which means that the PI stain entered the cells indicative of membrane damage (data not shown).
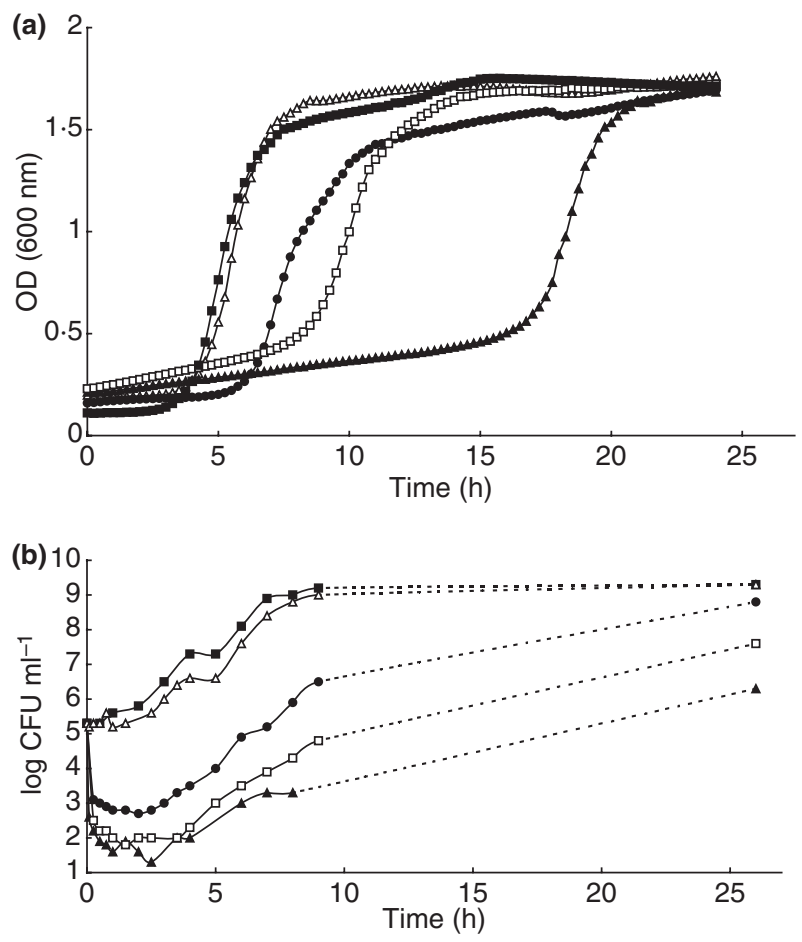

Figure 1 Influence of tempe extracts on vegetative cells of Bacillus cereus 14579. (a) Growth of B. cereus 14579 by optical density in Brain Heart Infusion (BHI) (closed square), cooked soya beans $10 \mathrm{~g} \mathrm{I}^{-1}$ (open triangle), tempe $1 \mathrm{gl}^{-1}$ fermented for $48 \mathrm{~h}$ (closed circle), tempe $10 \mathrm{~g} \mathrm{I}^{-1}$ fermented for $48 \mathrm{~h}$ (open square) and tempe $10 \mathrm{~g} \mathrm{I}^{-1}$ fermented for $24 \mathrm{~h}$ (closed triangle). For clarity of the figure, data points at 15-min interval are shown. (b) Viable count enumeration of $B$. cereus 14579 growth in BHI (closed square), cooked soya beans $10 \mathrm{gl}^{-1}$ (open triangle), tempe $1 \mathrm{~g} \mathrm{I}^{-1}$ fermented for $48 \mathrm{~h}$ (closed circle), tempe $10 \mathrm{~g} \mathrm{l}^{-1}$ fermented for $48 \mathrm{~h}$ (open square) and tempe $10 \mathrm{~g} \mathrm{I}^{-1}$ fermented for $24 \mathrm{~h}$ (closed triangle). The dotted lines are predictions of the growth between 9 and $26 \mathrm{~h}$.

After $24 \mathrm{~h}$ incubation of B. cereus in BHI with added tempe extract, lower numbers of viable cells were reached (Fig. 1b). Microscopic observations, however, showed that B. cereus formed long chains of rods in all three BHI with added tempe extracts samples compared to cooked and BHI without addition of tempe. This could result in less colonies on the agar plates and an underestimation of the viable cell count after $24 \mathrm{~h}$. This aggregation of bacterial cells was not observed after $15 \mathrm{~min}$.

The impact of soya bean extracts of the tempe processing stages on Bacillus cereus vegetative cells growth

During tempe processing, antibacterial activity of intermediate soya products was observed using the optical density assay. Growth delay caused by soya and tempe extracts of the successive stages of the processing are shown in Fig. 2a. Growth delays caused by raw, soaked 
and cooked soya beans, i.e., soya extracts of the processing steps before mould inoculation, were negligible. No effect of the soaking step, during which lactic acid bacteria actively develop, was observed. After inoculation with $R$. microsporus and incubation for $24 \mathrm{~h}$, the growth delay of $B$. cereus had increased up to $9.36 \pm 0.5 \mathrm{~h}$ (mean \pm standard deviation). Longer fermentation times resulted in less growth delay decreasing to $5 \cdot 33 \pm 0.08 \mathrm{~h}$ (mean \pm standard deviation) after $120 \mathrm{~h}$ of fermentation.
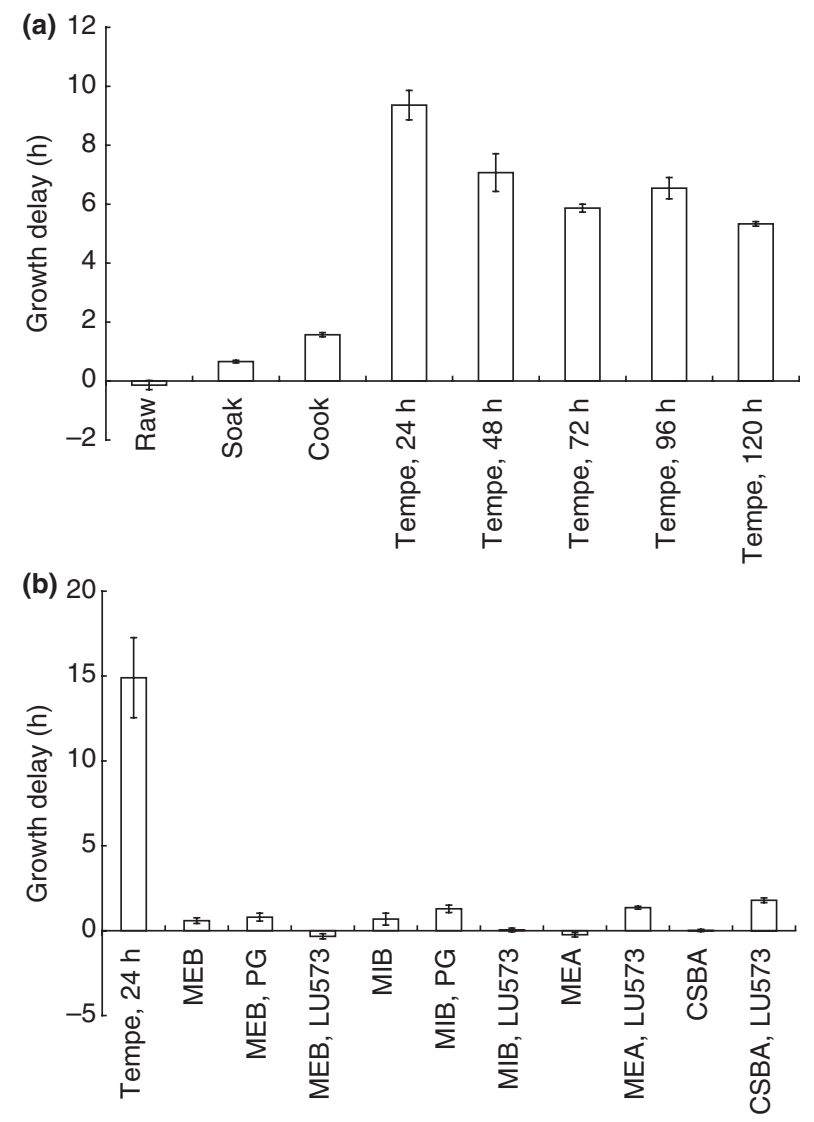

Figure 2 Growth delay measurement by optical density of Bacillus cereus 14579 after exposure to several extracts. (a) Growth delay of B. cereus 14579 after exposure to extracts $\left(10 \mathrm{~g} \mathrm{l}^{-1}\right)$ of several soya bean products during tempe processing. $X$-axis represents the several stages during tempe processing, respectively: raw soya beans (raw), soaked soya beans (soak), cooked soya beans (cook), tempe fermented for $24 \mathrm{~h}$ (tempe, $24 \mathrm{~h}$ ), tempe fermented for $48 \mathrm{~h}$ (tempe, $48 \mathrm{~h}$ ), tempe fermented for $72 \mathrm{~h}$ (tempe, $72 \mathrm{~h}$ ), tempe fermented for $96 \mathrm{~h}$ (tempe, $96 \mathrm{~h}$ ), tempe fermented for $120 \mathrm{~h}$ (tempe, $120 \mathrm{~h}$ ). (b) Growth delay measured of $B$. cereus after exposure to mould biomass grown in different media, and to corresponding postgrowth media. The concentration of the tempe (fermented for $24 \mathrm{~h}$ ) extract is $10 \mathrm{~g} \mathrm{I}^{-1}$ and of the mould extract is $1 \mathrm{~g} \mathrm{I}^{-1}$. MEB, malt extract broth; MIB, Mineral medium; MEA, Malt extract agar; CSBA, Cooked soya bean agar; PG, Postgrowth medium; LU573, inoculated with Rhizopus microsporus LU 573.
The antibacterial activity of $R$. microsporus grown on different media and their postgrowth media was also tested (Fig. 2b). Rhizopus microsporus grown on the different media, MEB, MIB, MEA and CSBA showed a growth delay $<1.8 \mathrm{~h}$, whereas the tested tempe extract showed a delay of $14.9 \pm 2.36 \mathrm{~h}$. Also the postgrowth media showed no activity towards $B$. cereus.

\section{Effect of soya bean extracts on germination and outgrowth of Bacillus cereus spores}

Bacillus cereus spores ( $\log 9 \mathrm{CFU} \mathrm{ml} \mathrm{m}^{-1}$ ) were incubated with and without soya bean extracts and monitored for their germination and growth. Figure 3(a) presents the results of the OD measurement. All samples showed a similar germination, as was manifested by an OD drop
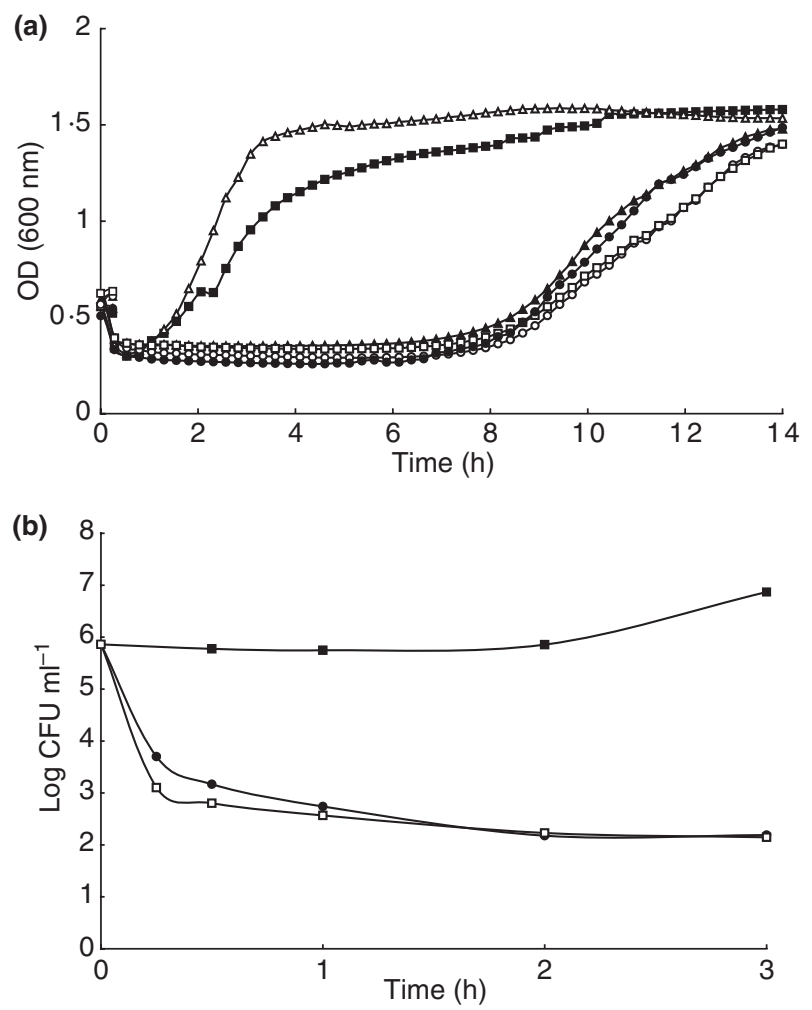

Figure 3 Influence of tempe extracts on spores of Bacillus cereus 14579. (a) Germination and outgrowth of spores by optical density in Brain Heart Infusion (BHI) (closed square), cooked soya beans $10 \mathrm{~g} \mathrm{I}^{-1}$ (open triangle), tempe $1 \mathrm{gl}^{-1}$ fermented for $48 \mathrm{~h}$ (closed circle), tempe $10 \mathrm{~g} \mathrm{I}^{-1}$ fermented for $48 \mathrm{~h}$ (open square), tempe $1 \mathrm{~g} \mathrm{I}^{-1}$ fermented for $24 \mathrm{~h}$ (open circle) and tempe $10 \mathrm{gl}^{-1}$ fermented for $24 \mathrm{~h}$ (closed triangle). For clarity of the figure, data points at 15-min interval are shown. (b) Viable count enumeration of $B$. cereus spores behaviour during $3 \mathrm{~h}$ incubation at $30^{\circ} \mathrm{C}$. Control growth in $\mathrm{BHI}$ (closed square), tempe $1 \mathrm{~g} \mathrm{I}^{-1}$ fermented for $48 \mathrm{~h}$ (closed circle) and tempe $10 \mathrm{~g} \mathrm{I}^{-1}$ fermented for $48 \mathrm{~h}$ (open square). 
within $1 \mathrm{~h}$ reflecting transition from the phase bright dormant phase into the phase dark germinated phase $(60 \%$ loss of optical density represents a germination of 100\%). After germination, the spores in BHI with or without added cooked beans extracts showed a normal pattern of outgrowth of vegetative cells. Spores germinated in BHI with added tempe extract showed a long 'lag' phase after germination, followed by an increase of optical density after $8 \mathrm{~h}$ indicating resumption of growth. The two tempe concentrations showed similar growth inhibition of B. cereus. Figure 3(b) presents development of viable counts of B. cereus after inoculation of spores in BHI with or without added tempe extract. A reduction of viable counts of $3.7 \log \mathrm{CFU} \mathrm{ml} \mathrm{m}^{-1}$ within $2 \mathrm{~h}$ was observed, with the fastest decrease of viable cells within the first $30 \mathrm{~min}$. This experiment also revealed similar effects of the different concentrations of tempe extracts used.

Spore germination and outgrowth in BHI with or without added tempe extract was monitored using phase-contrast and fluorescence microscopy (Fig. 4). After $15 \mathrm{~min}$ of incubation with and without tempe extract, dormant spores changed from phase bright to the phase dark stage. As was also shown in the OD-measurement (Fig. 3a), tempe did not hamper the first stage in spore germination. Phase-contrast and fluorescence microscopy showed that the phase dark spores with tempe were stained red, whereas the spores germinated in normal BHI were stained green. The red colour indicates the red-fluorescent membrane-impermeant dye PI to have entered the germinated spores signifying membrane damage by the incubation with tempe extract. After $2 \mathrm{~h}$ of incubation in BHI with added tempe extract, all spores still remained phase dark and appeared red-fluorescent (PI-stained) after livedead staining, whereas the spores that germinated in BHI had developed rod-shaped cells that appeared greenfluorescent (SYTO 9-stained) after staining.

\section{Tempe antibacterial spectrum}

Antibacterial activity of tempe was tested against different Bacillus spp. at two extraction pH: $\mathrm{pH} 7$ and $\mathrm{pH} 8$. Table 1 shows tempe to exert an antibacterial effect on all tested $B$. cereus strains and also on B. weihenstephanensis and $B$. subtilis. Tempe extracts at $\mathrm{pH} 8$ showed a longer growth delay than extracts obtained at $\mathrm{pH} \mathrm{7}$; extracts of tempe fermented for $24 \mathrm{~h}$ showed a longer growth delay than the tempe fermented for $48 \mathrm{~h}$ for all tested strains. No growth of any tested Bacillus strain occurred within the $22 \mathrm{~h}$ of the measurement in extracts of tempe fermented for $24 \mathrm{~h}$ and adjusted to $\mathrm{pH} 8$.

\section{Characterization of the inhibitory agent}

Tempe extracts were tested for their antibacterial activity after pre-incubation at different $\mathrm{pH}$ values, exposure to a range of enzymes and after heat treatment (Table 2). After $\mathrm{pH}$ adjustment of the tempe extracts, a growth delay of $B$. cereus could only be observed at $\mathrm{pH} 6$ and higher, with highest inhibition activity at $\mathrm{pH} 8$ and 9.

After treating tempe extracts with Pronase E or Proteinase $\mathrm{K}$, all antibacterial activity was lost. The activity was partly susceptible to the Protease type XIII and resistant to Trypsin and $\alpha$-Chymotrypsin.

After heat treatment exceeding $60^{\circ} \mathrm{C}$, the antibacterial activity was gradually lost. Heating up to $60^{\circ} \mathrm{C}$ resulted in an activity loss of about 20 and $60 \%$ in extracts of tempe fermented for 24 and $48 \mathrm{~h}$, respectively. Cooking led to complete loss of activity for the extract of 48-h-fermented
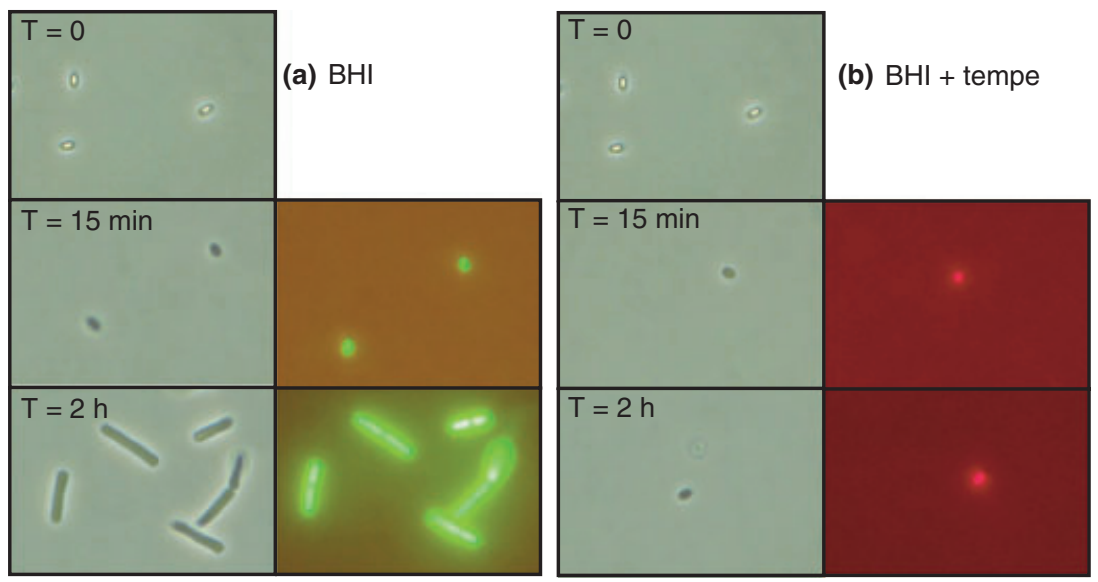

Figure 4 Spore germination and outgrowth in Brain Heart Infusion (BHI), as affected by added tempe extracts. Phase-contrast (left) and fluorescence (right) microscopy photographs of Bacillus cereus ATCC 14579 spores in BHI (a) and BHI supplemented with $1 \mathrm{~g} \mathrm{I}^{-1}$ tempe extract (b) after 0 min, $15 \mathrm{~min}$ and $2 \mathrm{~h}$. For fluorescence microscopy, the green fluorescent SYTO 9 and the red-fluorescent propidium iodide (PI) were used. 
Table 1 Growth delay (h) based on optical density of Bacillus strains exposed to tempe extracts

\begin{tabular}{|c|c|c|c|c|}
\hline \multirow[b]{3}{*}{ Strain } & \multicolumn{4}{|c|}{ Growth delay (h) } \\
\hline & \multicolumn{2}{|c|}{ Tempe, $24 \mathrm{~h} *$} & \multicolumn{2}{|c|}{ Tempe, $48 \mathrm{~h}^{*}$} \\
\hline & $\mathrm{pH} 7 \dagger$ & $\mathrm{pH} 8 \dagger$ & $\mathrm{pH} 7 \dagger$ & $\mathrm{pH} 8 \dagger$ \\
\hline B. cereus (ATCC 14579) & $9 \cdot 2 \pm 0 \cdot 4$ & $>16 \cdot 6$ & $6 \cdot 3 \pm 0 \cdot 1$ & $>16 \cdot 6$ \\
\hline B. cereus (B437) & $11 \cdot 7 \pm 4 \cdot 4$ & $>15 \cdot 1$ & $5 \cdot 3 \pm 0 \cdot 4$ & $13 \cdot 0 \pm 2 \cdot 9$ \\
\hline B. cereus (PAL 20) & $>16 \cdot 7$ & $>16 \cdot 6$ & $10 \cdot 8 \pm 1 \cdot 1$ & $13 \cdot 9 \pm 3 \cdot 9$ \\
\hline B. cereus (PAL 28) & $>16 \cdot 8$ & $>16 \cdot 7$ & $6 \cdot 6 \pm 0 \cdot 3$ & $10 \cdot 6 \pm 0 \cdot 0$ \\
\hline B. cereus (55) & $13 \cdot 7 \pm 0 \cdot 4$ & $>16 \cdot 4$ & $7 \cdot 1 \pm 0 \cdot 3$ & $>16 \cdot 4$ \\
\hline B. weihenstephanensis (DSM 11821T) & $12 \cdot 6 \pm 3 \cdot 1$ & $>15 \cdot 6$ & $7 \cdot 5 \pm 0.0$ & $13.9 \pm 2.5$ \\
\hline B. cereus (ATCC 10987) & $>16 \cdot 6$ & $>16 \cdot 3$ & $15 \cdot 2 \pm 2 \cdot 0$ & $>16 \cdot 3$ \\
\hline B. subtilis & $10 \cdot 9 \pm 2 \cdot 2$ & $>12.5$ & $>12.5$ & $>12.5$ \\
\hline
\end{tabular}

Growth delay is expressed as mean \pm standard deviation.

*Tempe extracts $10 \mathrm{~g} \mathrm{I}^{-1}$ in Brain Heart Infusion of 24-h and 48-h-fermented tempe.

$\dagger$ Growth delay measured at $\mathrm{pH} 7$ and $\mathrm{pH} 8$.

$>$ Means that the growth delay is longer than the total measurement period (22 h)

tempe, whereas the 24-h sample retained $30 \%$ of its activity. Notably, the 24-h-fermented tempe was more active than the 48-h-fermented tempe and was also more resistant to low $\mathrm{pH}$ and higher temperatures.

\section{Discussion}

This study describes the antibacterial effect of soya bean extracts of intermediate stages of processing and fermentation of tempe on B. cereus vegetative cells and spores. The antibacterial activity was found to be specific for tempe extracts and was sensitive to heat, low $\mathrm{pH}$ and proteases, indicating its proteinaceous nature.

Two antibacterial activity assays were performed, using optical density monitoring and viable count enumeration (Fig. 1). Both showed a rapid bactericidal effect by a long growth delay of $12 \mathrm{~h}$ and a reduction in viable count of $3.7 \log \mathrm{CFU} \mathrm{ml} \mathrm{m}^{-1}$ of the B. cereus cells after addition of tempe extract. After several hours, a regrowth of the bacteria was observed in both experiments and could be explained by either degradation of the active component or a surviving subpopulation. Conceivably, enzymes produced by $B$. cereus or produced by the mould during fermentation could be responsible for this reduction of antibacterial activity of the tempe extracts. Indeed, when $B$. cereus overnight culture supernatants were added to tempe extracts, the antibacterial activity of tempe was reduced to $10 \%$ of its initial value (data not shown). It is known that Bacillus spp. can produce a diversity of soluble extracellular enzymes (Priest 1977), including proteases that may inactivate the active component(s).

Experiments with B. cereus spores showed that tempe could inactivate spores upon their germination. The optical density data (Fig. 3a) demonstrate the transition of phase bright spores into phase dark spores, followed by outgrowth of the vegetative cells. The spores in BHI with added tempe extract showed a growth delay of around $6 \mathrm{~h}$ compared with the spores growing in control $\mathrm{BHI}$, which suggests that only a small surviving subpopulation of spores was able to grow. Fluorescence microscopy experiments showed that after addition of tempe extract (Fig. 4b), the phase dark spores (after germination) were stained red by PI, which indicates that tempe extracts induced considerable membrane damage to the germinated spores as was observed also with vegetative cells. The effect of tempe on dormant spores could not be measured as the tempe extracts already triggered the germination of the spores to the phase dark stage. Mechanistic information about effects of antibacterial compounds against spores is limited. A recent study, concerning the well-known antibacterial compound nisin, showed nisin to act against germinated spores of Bacillus anthracis and not against dormant spores. The mode of action of nisin responsible for outgrowth inhibition of B. anthracis spores appeared to involve inhibition of the oxidative metabolism and dissipation of the membrane potential, indicative of disruption of membrane integrity (Gut et al. 2008). Although our results also point to membrane targeting of the antibacterial activity of tempe extracts, the active component is different from nisin, based on its sensitivity to heat and low $\mathrm{pH}$, and its inactivation by a range of proteases.

In the research by Wang et al. (1969) and Kobayasi et al. (1992), antibacterial activity of $R$. oligosporus grown in culture broth was investigated. In contrast, we were not able to determine antibacterial activity of $R$. microsporus grown in culture broth, even when it had been grown on cooked soya bean agar. However, after the 
Table 2 Effect of pH, enzyme and heat treatments on growth inhibition activity of tempe extracts against Bacillus cereus ATCC 14579

\begin{tabular}{|c|c|c|}
\hline \multirow[b]{2}{*}{ Treatment } & \multicolumn{2}{|l|}{ Activity (\%) } \\
\hline & Tempe, $24 h^{*}$ & Tempe, 48 h* \\
\hline \multicolumn{3}{|l|}{$\mathrm{pH}$} \\
\hline 2 & $0.4 \pm 0.8$ & ND \\
\hline 3 & $2 \cdot 0 \pm 0 \cdot 8$ & ND \\
\hline 4 & $0.5 \pm 0.8$ & ND \\
\hline 5 & $17 \cdot 3 \pm 1 \cdot 7$ & $15 \cdot 8 \pm 4 \cdot 5$ \\
\hline 6 & $54 \cdot 2 \pm 2 \cdot 3$ & $16 \cdot 9 \pm 1 \cdot 3$ \\
\hline $7 \cdot 1$ (control) & $100 \pm 7 \cdot 8$ & $100 \pm 4 \cdot 7$ \\
\hline 8 & $>100 \dagger$ & $>100 \dagger$ \\
\hline 9 & $>100 \dagger$ & $>100 \dagger$ \\
\hline \multicolumn{3}{|l|}{ Enzyme } \\
\hline No enzyme (control) & ND & $100 \pm 14 \cdot 1$ \\
\hline Pronase E & ND & $-1 \cdot 8 \pm 0 \cdot 8$ \\
\hline Proteinase $\mathrm{K}$ & ND & $-3 \cdot 5 \pm 0 \cdot 3$ \\
\hline Protease XIII & ND & $67 \cdot 6 \pm 5 \cdot 4$ \\
\hline Chymotrypsin & ND & $101 \cdot 0 \pm 9 \cdot 2$ \\
\hline Trypsin & ND & $>100^{2}$ \\
\hline \multicolumn{3}{|l|}{ Heat $\left({ }^{\circ} \mathrm{C}, 20 \mathrm{~min}\right)$} \\
\hline 4 & $100 \cdot 0 \pm 5 \cdot 3$ & $100 \pm 12 \cdot 1$ \\
\hline 20 & $97 \cdot 6 \pm 5 \cdot 0$ & $99 \cdot 5 \pm 12 \cdot 6$ \\
\hline 30 & $106 \cdot 7 \pm 4 \cdot 9$ & $101 \cdot 7 \pm 10 \cdot 4$ \\
\hline 40 & $118 \cdot 2 \pm 6 \cdot 0$ & $99 \cdot 9 \pm 12 \cdot 8$ \\
\hline 50 & $131 \cdot 9 \pm 6 \cdot 2$ & $73 \cdot 9 \pm 10 \cdot 4$ \\
\hline 60 & $83 \cdot 9 \pm 5 \cdot 5$ & $42 \cdot 3 \pm 9 \cdot 1$ \\
\hline 70 & $47 \cdot 9 \pm 4 \cdot 9$ & $28 \cdot 8 \pm 8 \cdot 3$ \\
\hline 80 & $41 \cdot 1 \pm 5 \cdot 5$ & $18 \cdot 1 \pm 8 \cdot 5$ \\
\hline 90 & $33 \cdot 6 \pm 6 \cdot 9$ & $1 \cdot 8 \pm 7 \cdot 2$ \\
\hline 100 & $32 \cdot 2 \pm 6 \cdot 5$ & $-4 \cdot 0 \pm 7 \cdot 1$ \\
\hline
\end{tabular}

Activity is expressed in \% activity after treatment compared with the tempe without any treatment in the specific experiment. Activity is expressed as mean \pm standard deviation.

ND, not determined.

*Tempe extracts $10 \mathrm{~g} \mathrm{I}^{-1}$ of 24-h and 48-h-fermented tempe.

$\dagger$ No growth observed within measurement period.

fermentation of $R$. microsporus on soya beans, a high bactericidal activity was observed. It is conceivable that the antibacterial activity is produced by micro-organisms present in tempe, i.e. $R$. microsporus and LAB bacteria. This indicates on the one hand, that the antibacterial activity is only produced in situ, but on the other hand, it may indicate that degradation products of soya proteins are responsible for the antibacterial effect of tempe, thus pointing to an indirect role of the indicated micro-organisms. Notably, for milk-derived peptides such as bovine lactoferricin from lactoferrin and several peptides from casein, a strong antimicrobial activity was observed after microbial hydrolysis (López-Expósito and Recio 2008). Further characterization of the antimicrobial activity will shed light on this hypothesis.

To conclude, tempe extracts display antibacterial activity against $B$. cereus cells and spores by targeting the membrane of the bacteria. This bactericidal activity is released during fermentation of soya beans only, whereas extracts of raw, soaked and cooked soya beans, and $R$. microsporus grown in culture media did not give any antibacterial activity. The tempe antibacterial activity was found to be heat, low $\mathrm{pH}$ and protease sensitive, suggesting its proteinaceous nature. Further research will be required to identify the chemical nature of the antibacterial component(s) and its bio-functionality in terms of food preservation and pathogen control.

\section{Acknowledgements}

We thank Dr M. van der Voort, Laboratory of Food Microbiology for providing Bacillus cereus spores. This research was financially supported by the Graduate School VLAG.

\section{References}

Cotter, P.D., Hill, C. and Ross, R.P. (2005) Bacteriocins: developing innate immunity for food. Nat Rev Microbiol 3, 777-788.

Epand, R.M. and Vogel, H.J. (1999) Diversity of antimicrobial peptides and their mechanisms of action. Biochim Biophys Acta 1462, 11-28.

Galvez, A., Abriouel, H., Lopez, R.L. and Ben Omar, N. (2007) Bacteriocin-based strategies for food biopreservation. Int $J$ Food Microbiol 120, 51-70.

Gut, I.M., Prouty, A.M., Ballard, J.D., van der Donk, W.A. and Blanke, S.R. (2008) Inhibition of Bacillus anthracis spore outgrowth by nisin. Antimicrob Agents Chemother 52, 4281-4288.

Kobayasi, S.-Y., Okazaki, N. and Koseki, T. (1992) Purification and characterization of an antibiotic substance produced from Rhizopus oligosporus IFO 8631. Biosci Biotechnol Biochem 56, 94-98.

Kotiranta, A., Lounatmaa, K. and Haapasalo, M. (2000) Epidemiology and pathogenesis of Bacillus cereus infections. Microbes Infect 2, 189-198.

López-Expósito, I. and Recio, I. (2008) Protective effect of milk peptides: antibacterial and antitumor properties. $A d v$ Exp Med Biol 606, 271-293.

Notermans, S. and Batt, C.A. (1998) A risk assessment approach for food-borne Bacillus cereus and its toxins. Symp Ser Soc Appl Microbiol 27, 51S-61S.

Nout, M.J.R. and Kiers, J.L. (2005) Tempe fermentation, innovation and functionality: update into the third millenium. J Appl Microbiol 98, 789-805.

Nout, M.J.R., De Dreu, M.A., Zuurbier, A.M. and BonantsVan Laarhoven, T.M.G. (1987) Ecology of controlled soyabean acidification for tempe manufacture. Food Microbiol 4, 165-172. 
Priest, F.G. (1977) Extracellular enzyme synthesis in the genus Bacillus. Bacteriol Rev 41, 711-753.

Schaeffer, P., Millet, J. and Aubert, J.P. (1965) Catabolic repression of bacterial sporulation. Proc Natl Acad Sci USA 54, 704-711.

Settanni, L. and Corsetti, A. (2008) Application of bacteriocins in vegetable food biopreservation. Int J Food Microbiol 121, 123-138.
Stenfors Arnesen, L.P., Fagerlund, A. and Granum, P.E. (2008) From soil to gut: Bacillus cereus and its food poisoning toxins. FEMS Microbiol Rev 32, 579-606.

Wang, H.L., Ruttle, D.I. and Hesseltine, C.W. (1969) Antibacterial compound from a soybean product fermented by Rhizopus oligosporus (33930). Proc Soc Exp Biol Med 131, 579-583. 